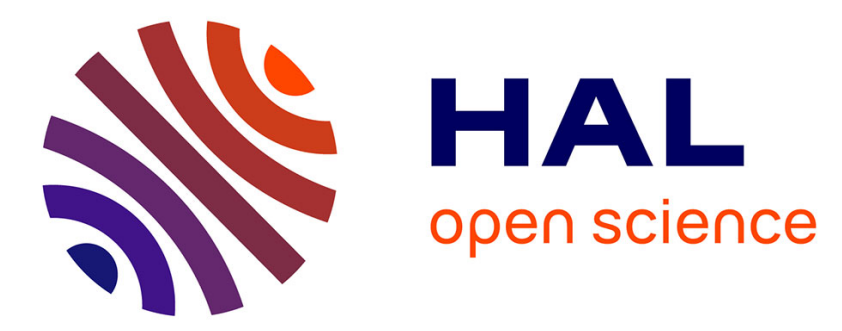

\title{
Characterisation of biodiversity in improved rubber agroforests in West-Kalimantan, Indonesia. Real and Potential uses for spontaneous plants
}

\author{
S. Diaz-Novellon, E. Penot, M. Arnaud
}

\section{To cite this version:}

S. Diaz-Novellon, E. Penot, M. Arnaud. Characterisation of biodiversity in improved rubber agroforests in West-Kalimantan, Indonesia. Real and Potential uses for spontaneous plants. Gergold G., Fremerey M., Guhardjae. Land-use, nature conversation and the stability of rainforest margins in Southeast Asia, Springerverlag, p1 à p 19, 2004. hal-00172480

\author{
HAL Id: hal-00172480 \\ https://hal.science/hal-00172480
}

Submitted on 17 Sep 2007

HAL is a multi-disciplinary open access archive for the deposit and dissemination of scientific research documents, whether they are published or not. The documents may come from teaching and research institutions in France or abroad, or from public or private research centers.
L'archive ouverte pluridisciplinaire HAL, est destinée au dépôt et à la diffusion de documents scientifiques de niveau recherche, publiés ou non, émanant des établissements d'enseignement et de recherche français ou étrangers, des laboratoires publics ou privés. 


\title{
Characterisation of biodiversity in improved rubber agroforests in West-Kalimantan, Indonesia. Real and Potential uses for spontaneous plants
}

\author{
Stéphanie Diaz-Novellon ${ }^{1}$, Eric Penot $^{2}$, Michel ARNAUD ${ }^{3}$. \\ ${ }^{1}$ Centre National d'Etudes Agronomiques des Régions Chaudes (CNEARC), 1101 \\ avenue Agropolis - BP 509834033 - MONTPELLIER cedex 01, diaz- \\ novellon@wanadoo.fr
}

${ }^{2}$ Cirad-Tera, programme TH, Montpellier, France : $\underline{\text { Penot@cirad.fr }}$

${ }^{3}$ Cirad-Tera, programme ERR, Montpellier, France, Arnaud@cirad.fr

\section{Introduction : the improvement of jungle rubber.}

Since the introduction of rubber at the turn of the $20^{\text {th }}$ century smallholders have developed an original complex agroforestry system called jungle rubber in which non selected young rubber trees (seedlings) are managed extensively alongside secondary forest re-growth.

The issue of improving smallholder rubber productivity at affordable capital investments and levels of inputs while maintaining the environmental benefits of jungle rubber has been addressed by the Smallholder Rubber Agroforestry Project (SRAP: a joint project run by ICRAF, GAPKINDO and CIRAD). In 1995-1996, 27 trials (with a total of 100 plots) were set up in three provinces in Indonesia to assess the possibility of associating clonal rubber with agroforestry practices under smallholder conditions (Penot, 1997). Two RAS types were selected for this study: RAS $n^{\circ} 1$ and $n^{\circ} 3$. RAS $n^{\circ} 1$ is basically improved jungle rubber using clonal planting material (see a description of RAS types in annexe 1). The rubber trees are in competition with spontaneous vegetation in the inter-row but results show that there are no negative consequences for rubber growth during the immature period. RAS $\mathrm{n}^{\circ} 3$ was designed for areas infested by Imperata cylindrica, 
with the establishment of shrubby leguminous cover crops and fast-growing tree species in the inter-rows with the aim of shading out weeds. The other type, RAS $\mathrm{n}^{\circ} 2$, is based on intercropping clonal rubber with various annual and perennial crops, including fruit and timber trees (Penot et al, 1994). In all cases, RAS have a planting density of 550 clonal rubber trees/ha and a variable number of associated fruit, timber or fast growing shade trees (from 92 to 256/ha).

In addition to the RAS experimental plots, "RAS sendiri" (or "endogenous RAS") are rubber agroforests improved by farmers without outside assistance.

The district of Sanggau in the province of West Kalimantan was identified by SRAP as representative of traditional jungle-rubber-based local farming systems that have developed over the last 90 years. The district of Sanggau is located in the central area of the Kapuas river basin, between $1^{\circ} \mathrm{N}$ and $0^{\circ} 6^{\prime} \mathrm{S}$ and $09^{\circ} 8^{\prime} \mathrm{W}$ and $11^{\circ} 33^{\prime}$ 'E. The district covers $18302 \mathrm{~km} 2$, i.e. $13 \%$ of the province. The trial plots described in this study are located in the villages of Embaong, Engkayu, Kopar, and Trimulia (the last being in the transmigration area).

Most soils in the province of West-Kalimantan are acrisoils associated with ferralitic soils. Such soils have relatively good physical characteristics but poor chemical value and become acid. Rubber is widely grown in this area as it can grow in poor soils. The landscape is dominated by logged-over forest, secondary forest and a mosaic of jungle rubber and fallow with secondary forest re-growth. Large scale logging activities took place from 1950s to the 1980s at the expense of primary forest. At present, forested areas are located in hilly or remote areas and are very limited in extent. Oil palm and Acacia mangium plantations developed exponentially in the 1990s increasing the conversion of degraded forest areas into Estates that cultivate perennial crops.

The main objective of this study is to assess existing plant biodiversity in RAS systems compared to that of jungle rubber. The second objective is to review the current uses of certain plants and their market potential.

\section{Methodology}

The data presented in this paper was collected between August and October 2001 in 4 villages in the West-Kalimantan provinces and included 23 rubber agroforests plots. The nature of the previous vegetation, neighbouring vegetation and soil characteristics were recorded in addition to classical data collected from plots used for on-farm trials (rubber growth. etc).

\subsection{Transect method}

In order to qualify existing biodiversity, the "transects" method was used with a sampling size per transect of $1 \mathrm{~m}$ x $0,2 \mathrm{~m}$, and 15 replications for each treatment. The measurement criteria for floristic analysis classically used with agroforestry 
systems are: i) abundance, ii) density, iii) frequency and iv) dominance. In addition, in our study data were collected on the number of species and identity.

This method was implemented to try and cover a wide range of situations. However, the results obtained with this method do not allow a direct comparison of biodiversity between cropping systems (between RAS and jungle rubber) because the initial plots (the transects) are too small. Further analysis merging replications into larger transects should provide information that will enable comparison of systems. Further research is therefore required, both in the field to cover a wider range of situations and in data processing to complete the picture. This paper presents the preliminary results.

\subsection{Statistical analysis : the use of correspondence analysis}

Statistical analyses (correspondence analysis) 1 was implemented using "Winstat", a software developed by CIRAD. This analysis allowed us to focus on different effects that influence plant biodiversity in rubber inter-rows under the different systems. The five first axes were taken into account for each analysis. Data were collected in RAS systems as well as in selected fallow plots with different densities of existing vegetation. The plotting was as follows: 23 RAS plots, fallow plots respectively 1,2,3,4 and 5 years old, 6-year-old jungle rubber plots (the same age as RAS plots), some tembawang plots (Tembawang are fruit and timber agroforestry systems developed by Dayak people) and some secondary forest plots near the study villages. Complete detailed results are available in Diaz Novellon's MSc. Thesis (2001)

The S-Plus software ${ }^{2}$ allowed us to implement discriminating analyses to explain variations in variables of diversity as a function of different explanatory variables (a "TREE function"). The selected variables of diversity were i) the number of species per replication, ii) the number of individuals in a replication (all species included) and iii) the ratios of individuals/number of species (N). These variables of diversity were correlated with different explanatory variables such as:

- The village: Kopar, Engkayu, Embaong, Trimulya;

- The farmer (21);

- The type of RAS (RAS 1 or RAS 3);

- The sub-type of RAS (RAS1.1/1.2/3.1/3.2/3.3/3.4) ${ }^{3}$;

- The treatment (A, B, C, D, E, F, G, H, I, J);

${ }^{1}$ In French : AFC = analyse factorielle des correspondances.

${ }^{2}$ This software is available on the web and is usually used for botanical analysis.

${ }^{3}$ RAS trials are subdivided to study one component per trial in order to keep the procedure very simple and useable by farmers. Treatments are planting density, type of clones, weeding intensity and so on 
- The surrounding plot environment (forest, fallow, jungle rubber, oil palm, etc.);

- The type of crop or vegetation before rubber (annual crops, Imperata cylindrica, Jungle Rubber, fallow, secondary forest, etc.)

\section{Assessment of the biodiversity under rubber agroforestry systems: a comparison between jungle rubber and RAS $n^{\circ} 1 \& 3$.}

Specific diversity, i.e. the number of species, appears to be higher in jungle rubber than in improved rubber agroforests (RAS).

Graph 1 and 2 show the main results of the effect of environmental factors and previous vegetation on the biodiversity of each system (graph 2) and a comparison of the density (number of species and replications) between RAS and jungle rubber of the same age (graph 3).

However, in RAS $n^{\circ} 3.4$ in which fruit and timber trees are planted in the interrows, the biodiversity of a number of species per transect is comparable to that of jungle rubber. A similar result was observed with "RAS sendiri". It thus appears that the different cultivation methods can directly influence the spontaneous diversity of plants in the inter-rows, and in fact, experimental RAS, RAS sendiri and jungle rubber are managed differently resulting in a significant "farmer effect" .

According to trial protocols discussed each year with project farmers the number of weedings in the inter-rows is higher in the case of RAS. In practice in RAS, weeding is limited to the selective cutting of trees and shrubs that grow taller than young rubber trees, as compared to jungle rubber, where there is no weeding at all during the first few years. Weeding appears to be the main factor that influences plants diversity. When the cutting of spontaneous vegetation of the inter-row is spread out over time, the number of species is higher. On the other hand, the type of rubber trees (clonal or seedlings) does not influence the type, the diversity and the quantity of vegetation. Inter-row biodiversity is therefore more influenced by the farming practices and in particular by the frequency of selective cutting or the number of weedings.

The distribution and biodiversity of RAS plots is shown in table 1 . 
Table 1: Distribution of plants per biological type for all plots

\begin{tabular}{cccccccc}
\hline & Trees & Herbaceous & $\begin{array}{l}\text { Lianas on } \\
\text { the } \\
\text { ground }\end{array}$ & $\begin{array}{l}\text { Lianas on } \\
\text { trees }\end{array}$ & $\begin{array}{l}\text { Bamboo } \\
\text { rattan }\end{array}$ & Shrubs \\
\hline Number of plants & 113 & 2480 & 368 & 128 & 54 & 231 \\
$\begin{array}{c}\text { Number of spe- } \\
\text { cies }\end{array}$ & 85 & 24 & 7 & 6 & 1 & 3 \\
\hline
\end{tabular}

One important question concerning the comparison between RAS and jungle rubber is whether jungle rubber has a higher specific plant density, i.e. the number of plants per unit area, than that of improved rubber agroforests.

Our results show that jungle rubber does indeed have more individual plants in inter-rows than RAS, although the density of plants is very similar to that of "RAS sendiri". The different agroforestry practices (and in particular the frequency of selective cuttings) explain this difference. In comparison to biodiversity in secondary forest or tembawang, the number of species appears to be similar to that of RAS when the ground-level density of species is considerably lower (see further tables). In other words, the difference is mainly quantitative.

What are the most significant factors that explain the variation in biodiversity? Discriminating analyses showed that previous farming practices are a significant factor. An area that had been cultivated for at least 3 years showed higher specific biodiversity than fallow. A possible explanation for this result is that cultivated areas as "open systems" have a more significant seed bank and can collect seeds from surrounding forests or agroforests. Environmental factors probably also influence biodiversity. The presence of jungle rubber in the immediate vicinity induces greater biodiversity. 1 to 5 years of fallow around plots probably also increases diversity. As far as agricultural practices are concerned, the number of selective cuttings per year appears to be the most significant factor influencing plant biodiversity in the inter-row ${ }^{4}$.

Previous results on jungle rubber biodiversity that were available to the author (Werner 97, De foresta, 97) as well as a guide book on plant uses (Levang \& al, 1991) provided very useful preliminary studies for this paper.

\section{Smallholders' perception of plant biodiversity.}

It was immediately clear that local populations know the plant species in their fields and their specific uses perfectly well. During field surveys as well as during interviews with farmers, more than 300 species had to be indexed. The most

${ }^{4}$ Detailed results are available in the $\mathrm{MSc}$ Thesis by the author, see bibliography (Diaz Novellon, 2001). 
common uses of spontaneous biodiversity (in forest and agroforests) are in order of importance: health (medicinal plants) food (fruit, vegetables), construction (wood and timber), firewood and others (see table 2).

Table 2: potential uses of biodiversity by the Dayak population

\begin{tabular}{cc}
\hline Uses & Number of species \\
\hline Timber for construction, housing & 83 \\
Firewood & 40 \\
Timber for sale or furniture & 2 \\
Fruits & 112 \\
Vegetables & 68 \\
Medicinal plants & 179 \\
Animal food & 24 \\
Pulp (for paper) & 1 \\
Cosmetics & 1 \\
Colouring properties & 2 \\
Use as paper & 9 \\
Weed control & 14 \\
Insecticide & 6 \\
Handicraft & 66 \\
Latex & 4 \\
Oil & 7 \\
Fertilisation & 14 \\
Spices & 55 \\
Others & 8 \\
\hline
\end{tabular}

However most spontaneous vegetation is not yet used by the local population and is thus available other for "potential uses". Medicinal plants have considerable potential (see table 3), as they are not widely used as farmers prefer "modern" drugs, which are considered to be far more effective against malaria, diarrhoea and other illnesses.

Table 3: Uses of medicinal plants.

\begin{tabular}{cc}
\hline Diseases cured by local plants & Number of identified species \\
\hline Coughs & 12 \\
Fever & 23 \\
Itching & 15 \\
Tiredness & 11 \\
Malaria & 2 \\
Dysentery & 1 \\
Throat & 13 \\
Toothache & 1 \\
Bellyache Belly sickness & 44 \\
Burns & 9 \\
Headaches & 11 \\
Others & 11 \\
\hline
\end{tabular}


In the case of timber and wood, the most valuable species (see table 4) are becoming scarce in the vicinity (in local forests) in the study area.

Table 4: Timber species that are becoming scarce in remaining forests

\begin{tabular}{lll}
\hline 0Local names & Latin names & Village \\
\hline Belian & Eusideroxylon zwageri & All villages \\
Tapang & Koompassia excelsa & Embaong, Kopar \\
Tekam & & All villages \\
Benkirai & Shorea sp & Embaong \\
Meranti & Shorea spp & Engkayu, Trimulya \\
Terenak & & All villages \\
Jeluntung & Dyera costulata & Trimulya \\
Kayu Raya & Shorea sp. & Kopar \\
Majau & Shorea palembanica & Embaong \\
Omang & Hopea dryobalanoides & Sanjan, Engkayu \\
Medang & Litsea elliptica & Kopar, Engkayu \\
Tunam & Shorea lamellata & Kopar \\
Nyatuh & Palaquium spp & Engkayu \\
Owan & & Engkayu \\
Ubah & Glochidion sp & Sanjan, Engkayu \\
& & \\
Taba & 0Aquilaria malaccen- & Kopar \\
& Sis & \\
Keladan & & Engkayu \\
Tengkawang & 1Dryobalanops bec- & \\
& Shorea macrophylla & Kopar \\
\hline
\end{tabular}

Most farmers are interested in integrating certain timber species see table 5) in their agroforests for both housing (construction) and sale.

Table 5: Timber species preferred by farmers.

\begin{tabular}{ll}
\hline Local names & Latin names \\
\hline Belian & 0Eusideroxylon zwageri \\
Keladan & Dryobalanops beccarii \\
Tekam & \\
Ketuat & \\
Meranti & Shorea spp \\
Terindak & Shorea senimis \\
Tengkawang & Shorea macrophylla \\
Mengkirai & 1Trema orientalis \\
& \\
Mentibu & Litsea elliptica \\
\hline
\end{tabular}




\begin{tabular}{ll}
\hline Nyatuh & Palaquium spp \\
Oman & Hopea dryobalanoides \\
Owan & \\
Jonger & Ploiarium alternifolium \\
Taba & Aquilaria malaccensis \\
Tantang & Buchania sessifolia \\
\hline
\end{tabular}

Prices vary considerably with the timber species, showing that this market is already well developed (table 6).

Table 6: Prices for local timber species

\begin{tabular}{lll}
\hline Timber species & Latin name & Price in rupiah \\
\hline Belian & 0Eusideroxylon zwageri & $50000 \mathrm{Rp} /$ board \\
& & \\
Raya & Ploiarium alternifolium & $3500 \mathrm{Rp} /$ board \\
Jonger & & $4000 \mathrm{Rp} /$ board \\
Owan & Litsea elliptica & $8000 \mathrm{Rp} /$ board \\
Medang & & $8000 \mathrm{Rp} /$ board \\
Paku & & $5000 \mathrm{Rp} /$ board \\
Tapang & Shorea macrophylla & $40000 \mathrm{Rp} /$ board \\
Tengkawang & Buchania sessifolia & $200000 \mathrm{Rp} / \mathrm{m} 2$ \\
Tantang &
\end{tabular}

Note : 1 US $\$=10500$ Rp in July 2001 .

Some local species are maintained or preserved by replanting or favouring regeneration from natural re-growth in the different types of agroforests (table 7) and have a range of different uses.

Table 7: Spontaneous timber species maintained in local agroforests and their uses.

\begin{tabular}{cll}
\hline Local names & Latin names & Uses \\
\hline Leban & Vitex pinnata & Timber, wood, spice, medicinal \\
Medang & Litsea elliptica & Timber, latex \\
Ramboutan & Nephelium lappaceum & Fruits, timber \\
Jengkol & Pithecellobium jiringa & Fruits, vegetable, timber, \\
& medicinal \\
Durian & Durio zibethinus & Fruits, timber \\
Pingam & Artocarpus sp & Fruits, timber, vegetable \\
Cempedak & Artocarpus integra & Fruits, medicinal, vegetable \\
Lengsat & Lansium domesticum & Fruits, medicinal, handicrafts \\
Pekawai & Durio c.f. dulcis & Fruits \\
Mentawa & Artocarpus c.f. anisophyl- & Fruits \\
& lus & \\
Nyatuh & Palaquium spp & Timber, latex \\
Owan & & Timber, handicrafts \\
\hline
\end{tabular}




\begin{tabular}{lll}
\hline Bungkang & Polyalthia rumpfii & Timber, spice \\
Belian & Eusideroxylon zwageri & Timber \\
Ubah & Glochidion sp & Timber \\
Kemenyan & Styrax benzoin & Timber, latex, animal food \\
Tantang & Buchania sessifolia & Timber \\
Bidara & Nephelium maingayi & Fruits \\
\hline
\end{tabular}

Some of these species have been re-introduced in agroforests (see table 8), in particular in "tembawang", or are protected when they emerge in natural regrowth in jungle rubber and RAS systems.

Table 8: Local species reintroduced in agroforest

\begin{tabular}{lll}
\hline Local names & Latin names & Uses \\
\hline Jengkol & & Fruits, vegetable, timber, medici- \\
& 1Pithecellobium jiringa & nal \\
Mangga & Mangifera indica & Fruits \\
Ramboutan & Nephelium lappaceum & Fruits, timber \\
Manggis & Garcinia mangostana & Fruits \\
Durian & Durio zibethinus & Fruits, timber \\
Cempedak & Artocarpus integra & Fruits, medicinal, vegetable \\
Coklat & & Cocoa \\
Kopi & & Coffee \\
Petai & Parkia speciosa & Fruits, vegetable \\
Lengsat & Lansium domesticum & Fruits, medicinal, handicraft \\
Kedupai & Mischocarpus pentapetalus & Fruits \\
Sibau & Xerospermum norotanum & Fruits \\
Mentawa & Artocarpus anisophyllus & Fruits \\
Pekawai & Durio c.f. dulcis & Fruits \\
Melinjo & Gnetum gnemon & Fruits, vegetable \\
Nangka & Artocarpus heterophyllus & Fruits \\
Tengkawang & Shorea macrophylla & Fruits, oil, timber \\
Tekam & & Timber, handicraft \\
Ketuat & & Fruits, timber \\
Tempuih & Baccaurea sp & Fruits \\
Pisang & Musa spp & Fruits, vegetable, medicinal \\
\hline
\end{tabular}

Some other species that farmers do not consider suitable in RAS inter-rows were also identified (table 9). These species are in fact still used in that their products are still collected in true forests, but are not specifically selected in agroforests due to the fact that - at least in the farmers' opinions - they may have a negative effect on rubber growth or production.in the farmers' opinions For example, after 20 years of growth the number of durian trees per hectare has to be limited to less than 20 to reduce shading when the durian's canopy begins to outgrow that of rubber. Another example is "tengkawang" (Illipe nut tree) which is considered to "dry" soils and therefore limit rubber trees growth (although this observation has not been scientifically confirmed). 
Table 9: List of species not chosen for agroforests and their uses

\begin{tabular}{|c|c|c|}
\hline Local names & Latin names & Uses \\
\hline Belangai & Eurya nitida & Timber, medicinal, handicraft \\
\hline Tucet & Alstonia angustifolia & Timber \\
\hline Plaik & Alstonia scholaris & $\begin{array}{l}\text { Timber, latex, medicinal, } \\
\text { handicraft }\end{array}$ \\
\hline Bamboo & & $\begin{array}{l}\text { Housing, handycraft, various } \\
\text { uses }\end{array}$ \\
\hline Todoh & Phrynium capitatum & Wrapping \\
\hline Ringkan & Ficus grossularoides & Fruits, wrapping, timber \\
\hline Resak & Melastoma malabathricum & $\begin{array}{l}\text { Timber, fruits, vegetable, me- } \\
\text { dicinal }\end{array}$ \\
\hline Pakis & & \\
\hline Semolang & Euodia aromatica & Medicinal, timber \\
\hline Siyet & Sceria prupurescens & Medicinal \\
\hline Entiup & Artocarpus sericicarpus & Fruits, oil, handicraft \\
\hline Leban & Vitex pinnata & Timber, spices, medicinal \\
\hline Jambu america & Bellucia axinanthera & Fruits, wrapping, timber \\
\hline Alang-Alang & Imperata cylindrica & Medicinal \\
\hline Marade & & Timber \\
\hline
\end{tabular}

Certain species (see table 10) may be selected to limit invasion of Imperata cylindrica in young agroforests.

Table 10: Species used to limit Imperata cylindrica $\left(\mathrm{alang}^{2}\right)$ in young agroforests.

\begin{tabular}{|l|l|l|}
\hline Local names & Latin names & Type of action \\
\hline Semenput & & Shading \\
\hline Beringing & & \\
\hline Melastoma & Melastoma malabathricum & Cover cropping \\
\hline Coklat & & Cover cropping \\
\hline Nenas & Ananas comosus & Root competition \\
\hline Gmelina & Gmelina arborea & Shading \\
\hline Orok-Orok & Crotolaria mucronata & Competition with alang \\
\hline Gamal & Gliricidia sepium & Shading (limited) \\
\hline Akacia & Acacia mangium & Shading \\
\hline Albizia & Albizia $s p$ & Shading \\
\hline
\end{tabular}


Table 11 summarises the different species in agroforests, "tembawang" and jungle rubber, RAS sendiri, RAS1 and RAS 3 as well as in "house gardens" of the local population (pekarangan) used and sold on local markets. It gives an idea of the wide variety of products that have an impact on both the household food supply and on the economy.

\section{Conclusion: Market potential}

Some forest products are of obvious economic interest (see table 11). Smallholders try to domesticate some of these species in the inter-rows of their agroforest (RAS and Jungle rubber), by replanting or favouring regeneration from natural re-growth, which has the advantage of involving almost no cost.

Timber species and fruit trees are particularly appreciated when they emerge from forest re-growth as they require no cost for plantation and very little additional labour to maintain. They are also replanted in order to enrich the vegetation in inter-rows.

Fruit trees have the most obvious potential market value, in particular durian (Durio zibethinus) which is already sold everywhere in Indonesia as well as in other countries in Southeast Asia (e.g. Thailand \& Malaysia), rambutan and dukus, the latter profiting from a keen demand on the Indonesian market. National markets do not yet appear to be saturated but export would provide the best market for smallholders, particular in the case of durian, which could easily be exported to neighbouring Malaysia, and north Borneo. The lack of larger organised marketing channels other than the traditional Sino-Indonesian one is a severe obstacle to the expansion of fruit markets and exports.

As a result of the keen demand for timber and wood products such as plywood in consumer countries (Japan, USA, and Europe), a timber shortage may already be expected in the very near future. Smallholders in West-Kalimantan would be well advised to anticipate this trend and include in their agroforests inter-rows species that can be used to supply the demand of the the plywood industry. Some species (Nyatoh in particular /Palaquium spp.) have a life-span similar to that of rubber ( 30 to 40 years). The ultimate life cycle of rubber agroforestry systems might then completed with the exploitation of timber trees such as Belian (Eusideroxylon zwageri),(lifespan 60 years) or meranti (up to 90 years). In this way, old rubber-based agroforests may develop into "tembawang". Finally, at the end of rubber life-span, rattan might prove to be a useful crop as indicated by the strong demand for furniture for export.

One important obstacle is the Indonesian legislation on land and tree tenure that needs to be re-examined and adapted to the context of smallholder production whose future potential could be highly significant. At present regulations concerning timber exploitation practically precludes trade in timber from forest or agroforest by smallholders. 
Other forest products with future potential are without any doubt medicinal plants. Local sales of these products although limited, has also gradually declined due to the effectiveness and availability of pharmaceutical products. However, pharmaceutical firms could be interested in several forest and agroforest species from Borneo and perhaps develop research projects that could indirectly benefit local populations. Examples of this type have been already been observed in other countries in Amazonia, as well as in Côte d'Ivoire where a product to control hypertension was discovered under rubber

Irrespective of how great the future potential of agroforest products is, and even if it is high for fruit, timber, rattan and medicinal plants, most products still remain under-exploited and this represents a great challenge for the very near future. Several contraints remain in terms of market organisation as well also as in terms of official regulations.

\section{References}

Diaz-Novellon S., Boutin D. Flora of rubber agroforests in the West Kalimantan Province. CD rom, SRAP, ICRAF-CIRAD Bogor, September 2001.

Diaz Novellon, S. (2001). Caractérisation de la biodiversité spontanée des agroforêts à hévéa en Indonésie : utilisation et potentialités des espèces utiles. CNEARC, Master of Sciences «Agronomie et Innovations en milieu rural ». Montpellier, CNEARC: 113 p.

De Foresta, H. (1997). Smallholder rubber plantations viewed through forest ecologist glassess. An example from South Sumatra. ICRAF/SRAP workshop on RAS (Rubber Agroforetsry Systems), Bogor.

Levang, P. and H. d. Foresta (1991). Economic plants of Indonesia : a Latin, Indonesian, French and English dictionary of 728 species. Bogor, Orstom - Seameo/Biotrop.

Penot, E. (1997). Introduction to SRAP methodology and concepts: summary of the preliminary results. The ICRAF/SRAP Workshop on RAS (Rubber Agroforestry Systems), September 1997, ICRAF, Bogor.

Penot, E. (1999). "Rubber Agroforestry Systems (R.A.S.) methodology and main results : technical report." CIRAD/ICRAF, project paper. Montpellier, February 1999.

Werner, S. (1997). Biodiversity of jungle rubber in West-Kalimantan. ICRAF/SRAP workshop on RAS (Rubber Agoforestry Systems), Bogor. 


\section{Annexe 1: description of the various RAS cropping system}

\section{RAS 1: an improved jungle rubber.}

The first system (RAS 1) is similar to the current jungle rubber system, in which unselected rubber seedlings are replaced by clones selected for their potential promising adaptation. These clones must be able to compete with the natural secondary forest growth; various planting densities and weeding protocols are tested. The biodiversity is very similar to that of jungle rubber, being itself close to that of secondary forest of the same age. (H. de Foresta, 1997). This system is similar to that originally tested by the dutch in the 1930' and called "jungle weeding" (Dijkman, 1950) after estates planters recognize that with the same unselected planting material, yields of jungle rubber were very comparable to that of estates with high weeding and intensive management. This prove that rubber, at least unselected rubber (seedlings), could grow and produce well in a complex agroforestry system with no major incidence on production. Clonal rubber requires definitely more weeding and maintenance that seedlings. The idea of RAS 1 is to reintroduce clones in a jungle rubber environment and to assess the minimum maintenance required for rubber to grow well. The main hypotheses derives from the precedent statement : rubber production, to a certain extend, is not affected by associated trees. In RAS 1, associated trees are not selected. These trees are those than grow naturally, however, farmers do a selection at opening (between 8 and 15 years after planting).

One main question might be the following " With an early opening (at 5/6 years old compared to $8 / 15$ years with jungle rubber)), and consequently an earlier canopy closure : is biodiversity composition and evolution will be different ?, can we therefore expect the same type of biodiversity?

\section{RAS 2 : an intensified rubber agroforest with intercrops.}

The second, RAS 2, is a complex agroforestry system in which rubber (550/ha) and perennial timber and fruit trees (92 to 152 trees/ha) are established after slashing and burning. It is very intensive, with annual crops being intercropped during the first 3 or 4 years, with emphasis on improved upland varieties of rice, with various amounts of fertilization as well as dry season cropping such as groundnut.

In that case, the number and type of trees associated to rubber are deliberately chosen at planting time. 
Several combination of planting densities (92, 140 and 250 trees/ha) and of selected species are being tested according to a tree typology, in particular : rambutan, durian, petai and tengkawang. Biodiversity is limited to the planted species as well as those which naturally regenerate and are eventually selected by farmers.

\section{The various types of RAS 2}

In RAS 2.1 : Each field is divided in 5 plots (rubber $+\mathrm{X}$ ) : rubber alone, Durian, Rambutan, Durian + Rambutan, farmer 's Mix (a combination of various fruit and timber trees)

In RAS 2.2 : fruit and timber trees are planted at 3 planting densities : 92, 140 and 150 trees/ha with rubber 550 trees/ha with a maximum of 30 big trees such Durian or timber trees. These planting density are within the range of what farmers already do in Sanjan for instance, without noticeable change in rubber production.

In RAS 2.5, rubber is combined with cinnamon (in the Jambi province) Cinnamon is collected at the $8^{\text {th }}$ year. Cinnamon at 1000 trees $/$ ha is planted with rubber 550 trees/ha in RAS 2.5 .

\section{RAS 3: a rubber agroforest adapted to Imperata grassland}

The third system, RAS 3, is a complex agroforestry system with rubber and other trees planted with a frame similar to that of RAS 2; the difference is that it is established on degraded lands covered by Imperata cylindrica, or in area where Imperata is a major threat.

Imperata increase rubber immature up to $8 / 9$ years ( $G$ Wibawa, 1995). Labour or cash for controlling Imperata with herbicide are the main constraints. In RAS 3 , annual crops, generally rice, are grown the first year only, with non vine cover crops grown immediately after rice harvesting ( Mucuna, Flemingia, Crotalaria, Setaria and Chromolaena) with a selection of trees : fruit and timber trees, multipurpose trees (wingbean, Gliricidia.. ) and fast growing trees as pulpwood for shading (Paraserianthes falcataria, Acacia mangium or crassicarpa and Gmelina arborea have been selected in West Kalimantan. The objective here is to eliminate the weeding constraint after the first year by providing a favourable environment for rubber and associated trees and consequently suppressing Imperata with low labour requirements. Several design and combination have been tried in RAS 3 in West Kalimantan. 


\section{The various types of RAS 3}

\section{RAS 3.1 (planting in 1995) : a preliminary test.}

The different treatments where based on the use of the following trees (1 per treatment): Leucena leucocephala, Gliricidia sepium, Caliandra callothyrsus, Ceasalpinia sappam, Chromolena odorata and Flemingia congesta with classical LCC (legume cover crops) as a control. In addition , 250 fruit and timber trees are combined with 550 rubber/ha

\section{RAS 3.2 (planting in December 1996) : confirmation test.}

This trial was established according to the results of RAS 1 trial with the following trees : Gliricidia s., Gmelina a., and the following cover crops: Chromolena odorata, Crotalaria and Mucuna spp.

The first control is rubber in monoculture + LCC. The second control is rubber monoculture + Imperata. In addition , 250 fruit and timber trees are combined with 550 rubber/ha

\section{RAS 3.3 : no associated fruit/timber trees : pulp trees only}

A first set of 4 replications has been planted in January 1996. The selected trees have been the following: Paraserianthes falcatarian Acacia mangium and Gmelina arborea. Rubber is at 550 trees/ha as well as pulp trees in the interrow ( 3 meters between tres on the pul tree line and 3 meters apart from the rubber line). The covercrop is Flemingia.

\section{RAS 3.4 : pulp trees + associated trees.}

Same structure as RAS 3.3 with 1 pulp tree out of 3 replaced by associated fruit/timber trees: in that case : the planting densities are for rubber : 550/ha, for pulp trees : 460/ha and for associated trees : 92/ha 
Table 11: Species and products already sold on local

\begin{tabular}{|c|c|c|c|}
\hline Indonesian/local names & Latin names & Sale price & Origin \\
\hline $\begin{array}{l}\text { Pisang / Banana } \\
\text { Pakis piding / ferns }\end{array}$ & Musa spp. & $\begin{array}{l}1500 \mathrm{Rp} / \mathrm{lot} \\
500 \mathrm{Rp} / \mathrm{lot}\end{array}$ & $\begin{array}{l}\text { Agroforêst } \\
\text { Agroforêst }\end{array}$ \\
\hline Kangkong & 2Ipomea aquatica & $500 \mathrm{Rp} / \mathrm{lot}$ & \\
\hline Cangkok manis & & $500 \mathrm{Rp} / \mathrm{lot}$ & Agroforêst \\
\hline Daun kacang/bean leaves & & $500 \mathrm{Rp} / \mathrm{lot}$ & Home garden \\
\hline Daun ubi / cassava leaves & Gnetum gnemon & $500 \mathrm{Rp} / \mathrm{lot}$ & Agroforest \\
\hline Bunga pisang/banana flower & Musa spp & $1000 \mathrm{Rp} /$ fleur & Agroforêst \\
\hline Jengkol & $\begin{array}{l}\text { Archidendron pauciflo- } \\
\text { rum }\end{array}$ & $1000 \mathrm{Rp} / \mathrm{Kg}$ & Agroforeesêt \\
\hline Maram & Eleiodoxa conferta & $2000 \mathrm{Rp} / \mathrm{Kg}$ & Agroforest \\
\hline Kacang panjang/bean & Vigna unguiculata & $2000 \mathrm{Rp} / \mathrm{Kg}$ & Home garden \\
\hline Timun /cumcumber & Cucumis sativus & $2000 \mathrm{Rp} / \mathrm{Kg}$ & Home garden \\
\hline Bunga jagung/maize flower & Zea sp & $500 \mathrm{Rp} /$ fleur & Pontianak \\
\hline Bayam & Amaranthus hybridus & $500 \mathrm{Rp} / \mathrm{lot}$ & Home garden \\
\hline Petai & Parkia speciosa & $2500 \mathrm{Rp} / \mathrm{Kg}$ & Agroforest \\
\hline Labu air / pumpkin & Lagenaria siceraria & $2500 \mathrm{Rp} / \mathrm{Kg}$ & Home garden \\
\hline Jahe / gingember & Zingiber officinale & $2500 \mathrm{Rp} / \mathrm{Kg}$ & Home garden \\
\hline Kelapa / coco nuts & Cocos nucifera & $1000 \mathrm{Rp} /$ fruit & Home garden \\
\hline Peringgi & & $4500 \mathrm{Rp} / \mathrm{Kg}$ & Home garden \\
\hline Kecambah & & $1000 \mathrm{Rp} /$ portion & \\
\hline Ubi / cassava & Manihot esculenta & $2500 \mathrm{Rp} / \mathrm{Kg}$ & Agroforest \\
\hline Kedondong & Spondias pinnata & $500 \mathrm{Rp} /$ lot & \\
\hline Pekawai & Durio c.f. dulcis & $10000 \mathrm{Rp} / \mathrm{lot}$ & Agroforest \\
\hline Terong & Solanum melongens & $5000 \mathrm{Rp} / \mathrm{Kg}$ & Home garden \\
\hline Cabe / pepper & Capsicum annuum & $20000 \mathrm{Rp} / \mathrm{Kg}$ & Pontianak \\
\hline Buncis & Phaseolus vulgaris & $3500 \mathrm{Rp} / \mathrm{Kg}$ & \\
\hline Gambas & Luffa acutangula & $2000 \mathrm{Rp} / \mathrm{Kg}$ & \\
\hline Jeruk / lemon & Citrus sp & $3000 \mathrm{Rp} / \mathrm{Kg}$ & Home garden \\
\hline Nangka / Jacqj fruit & Artocarpus heterophyllus & $2500 \mathrm{Rp} / \mathrm{Kg}$ & Agroforêst \\
\hline Kencur & Kaempferia galanga & $10000 \mathrm{Rp} / \mathrm{Kg}$ & \\
\hline Kunyit & Curcuma longa & $5000 \mathrm{Rp} / \mathrm{Kg}$ & Agroforest \\
\hline Serai & Cymbopogon nardus & $500 \mathrm{Rp} /$ lot & Agroforest \\
\hline Keladi & Colocasia esculenta & $1000 \mathrm{Rp} / \mathrm{lot}$ & Agroforest \\
\hline Kundur & Benincasa hispida & $2500 \mathrm{Rp} / \mathrm{Kg}$ & \\
\hline Asam & Tamarindus indica & $500 \mathrm{Rp} /$ fruit & Agroforest \\
\hline Labu siam & Sechium edule & $2500 \mathrm{Rp} / \mathrm{Kg}$ & Home garden \\
\hline Pane & Momordica charantia & $5000 \mathrm{Rp} / \mathrm{Kg}$ & Pontianak \\
\hline Wartel / carott & Daucus carota & $9000 \mathrm{Rp} / \mathrm{Kg}$ & Pontianak \\
\hline Jeruk nipis / lemon & Citrus aurantifolia & $4000 \mathrm{Rp} / \mathrm{Kg}$ & Pontianak \\
\hline Kol / cabbage & Brassica oleraceae & $5000 \mathrm{Rp} / \mathrm{Kg}$ & Pontianak \\
\hline Kentang / potato & Solanum tuberosum & $4500 \mathrm{Rp} / \mathrm{Kg}$ & Pontianak \\
\hline Tomat / tomato & Lycopersicon esculentum & $6000 \mathrm{Rp} / \mathrm{Kg}$ & Pontianak \\
\hline Bawang merah/red onion & Allium cepa & $7000 \mathrm{Rp} / \mathrm{Kg}$ & Pontianak \\
\hline
\end{tabular}




\begin{tabular}{llll}
\hline Bawang putih/white onion & Allium sativum & $7000 \mathrm{Rp} / \mathrm{Kg}$ & Pontianak \\
Kayu manis/cinnamon & Cinnamomum burmanii & $2000 \mathrm{Rp} /$ lot & Agroforest \\
Nenas / pinepale & Ananas comosus & $2000 \mathrm{Rp} /$ fruit & Agroforest \\
Sawih / cabbage & Brassica rugosa & $5000 \mathrm{Rp} / \mathrm{Kg}$ & Pontianak \\
Jambu air & Syzygium aquaeum & $1500 \mathrm{Rp} / \mathrm{Kg}$ & Home garden \\
Pepaya / papaya & Carica papaya & $2500 \mathrm{Rp} / \mathrm{Kg}$ & Home garden \\
Kenikir & Cosmos caudatus & $500 \mathrm{Rp} /$ lot & \\
Lengkuas & Alpinia galanga & $1000 \mathrm{Rp} /$ lot & Agroforest \\
Daun salam / leaves & Eugenia polyantha & $500 \mathrm{Rp} /$ lot & Agroforest \\
Daun sop /celery leaves & Apium graveolens & $1000 \mathrm{Rp} /$ lot & Home garden \\
Daun pepaya/ papaya leaves & Carica pepaya & $500 \mathrm{Rp} /$ lot & Home garden \\
Mangga & Mangifera indica & $8000 \mathrm{Rp} / \mathrm{Kg}$ & Agroforest \\
Petai & Parkia speciosa & $2000 \mathrm{Rp} /$ lot & Agroforest \\
Kacang tanah/peanut & & $3000 \mathrm{Rp} / \mathrm{Kg}$ & Home garden \\
Cempedak hutan & Artocarpus integra & $500 \mathrm{Rp} / \mathrm{fruit}$ & Agroforest \\
Kumis kucing & Orthosiphon aristatus & $1000 \mathrm{Rp} /$ lot & Home garden \\
\hline
\end{tabular}

NB : These species 's latin names should be utilized cautiously because of the difficulties of identification and correspondence between vernacular names and scientific names 
Graph 1: Effect of environmental factors and previous vegetation on agroforest biodiversity

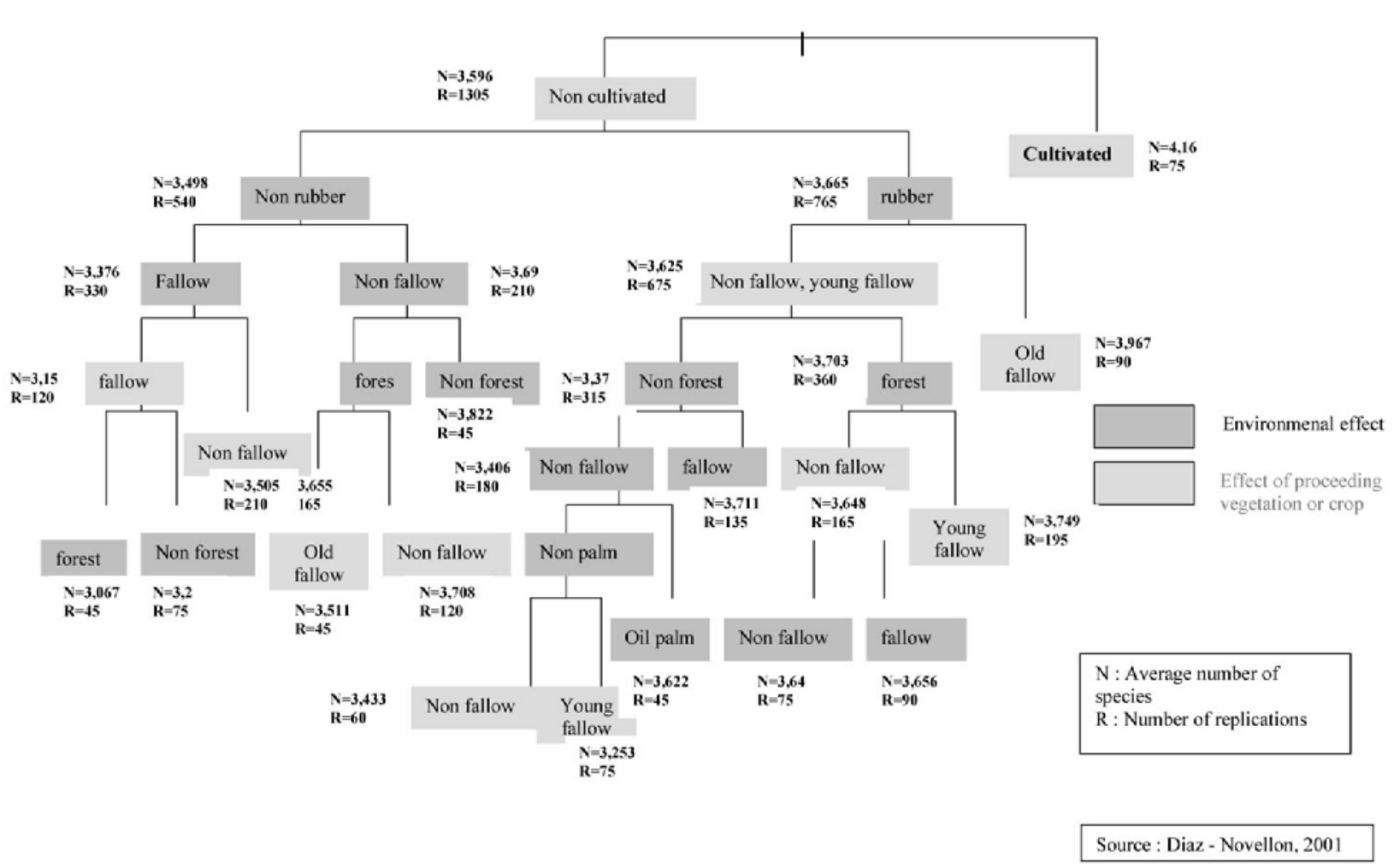




\section{Graph 2: Comparison of density in RAS and jungle rubber at the same}

age

$\mathrm{N}$ : number of species
$\mathrm{R}:$ number of replications

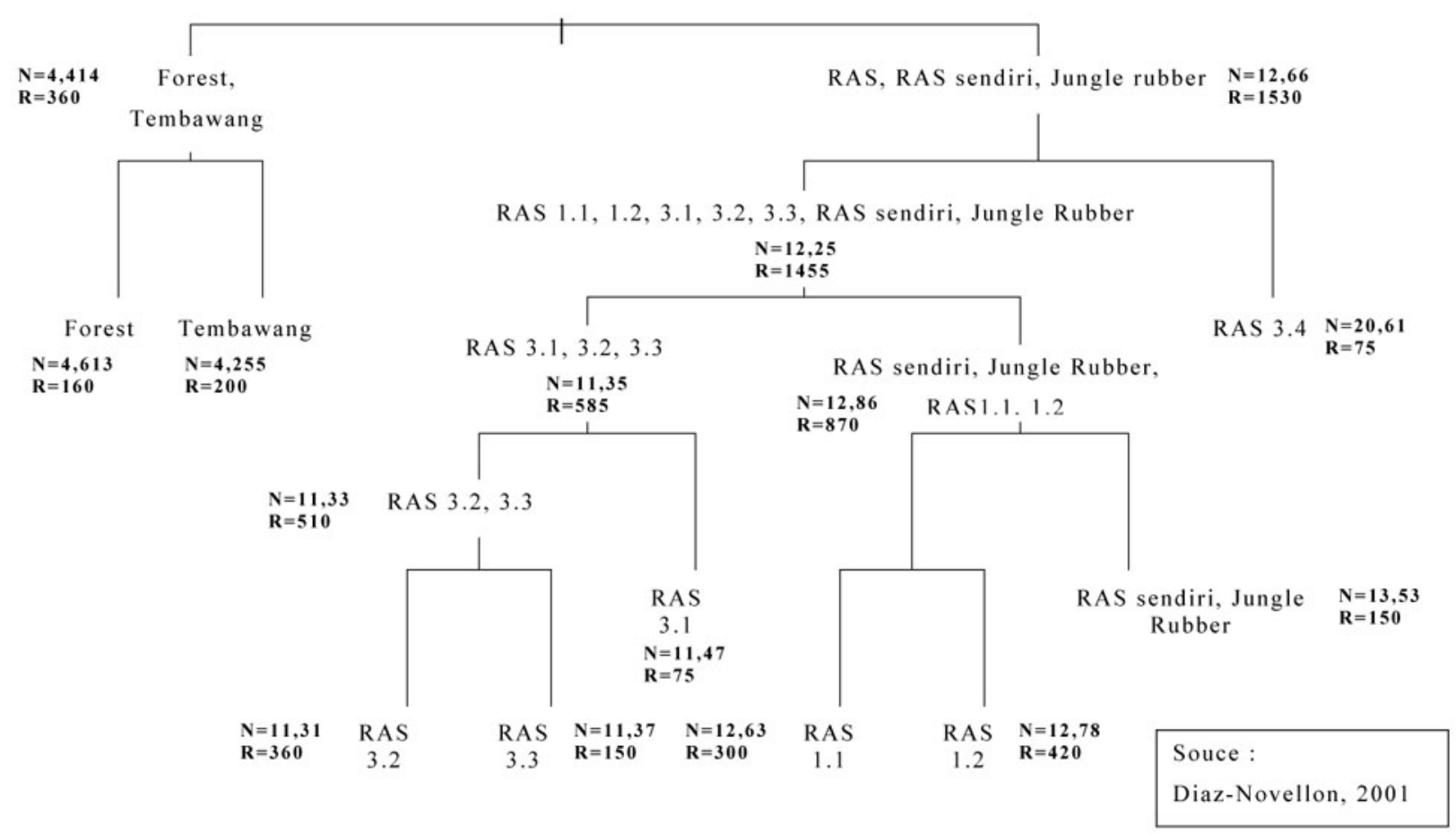

